\title{
Teaching Marginalized Grammar
}

\author{
Katsuhiro Ohashi \\ Ritsumeikan Asia Pacific University, Beppu City, Japan
}

\begin{abstract}
When Ferdinand de Saussure (1916) granted priority to synchronic linguistics over diachronic linguistics, his intention was not to ignore the fact that language is fundamentally a historical entity. How would a linguist, who recognized the inherent historicity of language to the fullest (de Saussure, 1916), have pronounced a practical abnegation of diachronic linguistics? His prioritization of synchrony should be construed as no more than a methodological expediency. Yet far from being a mere pedagogic expediency, the primacy of synchrony as a core assumption behind modern language teaching has gone to such an excess as to perpetuate a falsified image of language as ahistorical. For any true cause of TESL (teaching English as a second language), this is a corrigendum of the first order of importance. The current investigation is motivated by a sense of need to unlearn such a specious assumption and reestablish TESL on a symmetrized balance between synchrony and diachrony. To meet this specific need, the idea of synchro-diachronic concomitance will be brought into discussion as lying at the heart of the MH (Marginalization hypothesis).
\end{abstract}

Keywords: diachrony, synchrony, synchro-diachronic concomitance, MH (Marginalization hypothesis)

\section{Introduction}

Throughout the OE (Old English) period, the boundary between the th-form and $y$-form of second-person pronouns was defined on the simplex basis of a number distinction: The former was for a single second-person and the latter for two or more second-persons. It is widely known that the influence of Norman French that had already transferred the historically plural vous to a deferential singular second-person pronoun gave rise to the transference of the $y$-form to a polite form of address to a single second-person in ME (Middle English) and that the use of the $t h$-form got restricted to an equal or inferior single second-person consequent on that. Thus the complex demarcation between th-form (intimate singular) and $y$-form (plural + polite singular) was instituted in ME and EModE (Early Modern English). For better or for worse, after the th-form was lost at the end of the 17th century, all that is available to standard ModE (Modern English) speakers is the $y$-form irrespective of whether they are addressing a single second-person politely or intimately as well as whether they are talking to just one or more than one second-person.

Language teaching as it is known to us is premised on the assumed primacy of the synchronic system of a target language over its diachronic systems, and so is TESL (teaching English as a second language). As things are, this primacy is purported to reign so unchallenged that it will be hard to come by TESL materials that make if only a passing reference to the above-mentioned pre-ModE usages of personal pronouns. For the 
moment, let us agree that TESL should stay as it is on a tentative assumption that there is nothing wrong about its predilection for synchrony theoretically as well as in practice. But then, it is not conceivable for TESL's target to be the language not anchored in time any more than it is thinkable that the object of descriptive linguistics be a temporally unanchored language. Just as it is counterproductive for linguists whose job is to describe the current state of a given language to divert their attention from synchrony, so for teachers of English as a second language to ramble on about the good old days of their target language is not just futile, but it is doing less than justice to it inasmuch as ModE and pre-ModE are such discrepant systems that knowing this does not illuminate the way to that as revealingly as focusing on the English of our day. Such, in brief, can be the justification for the universally taken-for-granted supremacy of synchrony over diachrony with which TESL is theoretically armored.

It is all very well to harp on about an argument like that, but the reality of language is nothing like such a synchronic monolith. One serious failing of the modern current of language teaching - behind its crowning achievements - consists in its intrinsic inability to give diachrony its due as a vital and active part of a synchronic system. It is this lack of panchronic perspective in modern thinking about language teaching with which TESL has been and doubtless still is beset that has been on the mind of the present author as a defect of profound significance standing in the way modern languages including English should be taught. What follows is intended to open the question of this specific lacuna within TESL and close it with a certain prescription. Since it is the kind of question utterly unsolvable as long as we stay within the theoretical resources of TESL's own making, our first step should be toward freeing TESL from the tyrannical hold of the monochronic view of language in favor of a panchronically synthetic view. This recognition prompts us to go back to the MH (Marginalization hypothesis).

\section{Marginalization Hypothesis}

The $\mathrm{MH}^{1}$ as advanced by the present author views synchrony as a dual structure consisting of unmarked mainstream and marked marginal and counters a commonly held view of the latter as peripheral to our grasp of a synchronic system; on the hypothesized ground that the marked parts of a synchronic state en masse play a uniquely valuable, if subservient, role in the working of a living language, the MH contends that synchrony is an alliance of unmarked and marked values. To illustrate the crux of its contention with the ModE paradigms of be-verb (see Table 1), the hypothesis speaks of them in terms of a double-decker structure in which two irregular pieces of marginal, i.e., "I am" and "You (Singular) + Plural V (are/were)" are superimposed on the regular "Singular S + Singular V (is/was)" and "Plural S + Plural V (are/were)" mainstream. Thus Table 1 typifies a dual structure of marginalized irregular syntagmas ("I am" and "Singular You + Plural V [are/were]") encapsulated within the matrix of the mainstreamed regular syntagmas ("Singular S + Singular V [is/was]" and "Plural S + Plural V [are/were]").

The MH does not stop articulating its critical point here. On the basis of the historical facts that am is a residue of old suppletivism and that "You (Singular) + Plural V (are/were)" is a modern transference of the $\mathrm{OE}$ "ge (later ye) + are/were" syntagma, it goes on to allege that history's legacy is broadly equatable with

\footnotetext{
${ }^{1}$ See Ohashi (2011) for a fuller account of the Marginalization hypothesis.
} 
the marginalized elements of a synchronic system, be they grammatical, lexical, or phonological, and proposes to redefine language as an interplay of history (marked) and now (unmarked). In other words, by virtue of holding a high opinion of the marginalized part of a language as a foil to the mainstreamed part yet with its own contributions to add, the MH exploits the structuralist dichotomization between synchrony and diachrony in such a way as to portray language as a synthetic whole whose dichotomous parts do not come into conflict but enter into alliance, each complementing the other, as twin shapers of a living language ("synchro-diachronic concomitance").

Table 1

ModE Paradigms of Be-Verb

\begin{tabular}{|l|l|l|l|}
\hline Singular & I & am & was \\
\hline & You & are & were \\
\hline & He/She/It & is & was \\
\hline Plural & We & are & were \\
\hline & You & are & were \\
\hline & They & are & were \\
\hline
\end{tabular}

The MH is an expression of the current author's concern about the conventional overestimation of the mainstream and as conventionalized overlooking of the significance of the role assigned to and fulfilled by the marginal within a synchronic context that continues to prevail not just in linguistic studies but also in language teaching. For reasons stated in the foregoing paragraph, rethinking thus motivated should manifest itself in the form of an effort to revivify history's role in the engineering of a living language and to reinstate, by so doing, the part played by historical legacy within a synchronic drama.

It is such a panchronic view that cuts through the pages of this largely experimental attempt to review TESL in a fresh light. Getting back to Table 1, it is a widespread practice that teachers single out the mainstreamed, regular part of that locality of ModE grammar, i.e., "Singular S + Singular V (is/was)" and "Plural S + Plural V (are/were)", and leave aside the marginalized part of the table as heterogeneous, irregular factors for learners to acquire by rote. The downside of this otherwise most efficient approach to TESL is the likelihood that those learners who are curious, fairly enough, how such an irregularity (e.g., "Singular You + Plural V (are/were)") has crept into Table 1 will remain frustrated. Advantageously, the MH-based teaching can offer a historical answer to such a question. Just tell, "You is historically a plural pronoun", and two things of a kind that may make a vital difference are expected to happen: First, those inquisitive minds can get their curiosity immediately satiated; and second and more important, they will begin to capture if only a tip of one fundamental truth about the fabric of language, viz., that the mutually dependent relation of history and now is built into the structure of any language so as to make its synchronic system prove fully equal to the demands of whatever calls for expression. It is with a combination of these two expectations in mind that we will start out to explore TESL problems afresh.

In what follows, a selected number of morphological issues that TESL cannot possibly dodge will come under scrutiny with a view to testing the viability of MH-based teaching as a possibly fruitful alternative to the way TESL now stands. To syntactic, phonological, and lexical questions, which merit as in-depth re-examinations, should be devoted separate discussions. 


\section{Morphologically Marginalized Grammar}

\section{The Subjunctive}

The 19th century American philologist Whitney (1901) wrote: "The subjunctive has very nearly gone out of use in Modern English. This is true especially for its preterit tense. No verb except be has a preterit subjunctive that differs from the indicative" (p. 111). In corroboration, Danish linguist Jespersen stated: "[I]n English the subjunctive has since Old English times been on retreat" (1992, p. 318) and "[i]n the preterit only one verb has a subjunctive form that is distinct from the indicative, and that only in the singular: were (indicative was)" (1972, p. 293). Scores of years after the two gurus gave expression to the decline of the subjunctive, their assertions seem more valid than they used to as observed by grammarians of today who claim that "[t]he subjunctive is not an important category in contemporary English" (Quirk, Greenbaum, Leech, \& Svartvik, 1972, p. 76).

The subjunctive is one of the most difficult experiences for English teachers, to say nothing of its learners. Those without any amount of specialized training in linguistics are not likely to see the points made above by Whitney and Jespersen to the full, still less able to teach the subjunctive as it is expounded in linguistics. Faithful to its etymological sense (Latin, subjunct-"subjoin"), linguists tend to apply the term "subjunctive" to refer to the specific verb form used in the subordinate clause as far as ModE is concerned. As is evident from such examples as "him wære betere..." (OE [for him would be better...], as cited in Crépin, 1972, p. 89), "3et were it bet my tongue for to stille" (ME [Yet it would be better to hold my tongue in silence], Chaucer, 1382-1385, p. 230), and "that were a long lettyng" (ME [that would be a long delay], as cited in Burrow \& Turville-Petre, 2005, p. 49), the subjunctive were used to be employed in main clauses where ModE uses "would be". Citing "She were an excellent wife for Benedick (Sh.)" and "That were a pity! (= would be)", Jespersen (1972) wrote: “... were is still found in this way [i.e., in non-subordinate clauses] in literary language" (p. 257). Be this as it may, the fact remains that the term "subjunctive" should be employed in relation to main clauses as sparingly as possible where ModE is concerned. "[T]he impoverishment of the scheme of moods", said Whitney (1896) in his earlier work, "was compensated by the introduction of a rich apparatus of auxiliaries" (p. 107), suggesting that would and its kindred used in main clauses should be called modal auxiliaries, while Burrow and Turville-Petre (2005) were more elaborate when they noted: "As the distinctions between the subjunctive and the indicative forms - always only partial - were reduced, the subjunctive mood came more and more to be expressed by other means, in particular by the use of the modal auxiliaries" (p. 50).

If a distinction should be drawn between the subjunctive (specific morphologies of full verbs used in subordinate clauses) and the modals (auxiliaries used in main clauses) as linguists claim, it follows that the were embedded within the subordinate clause in "I wish she were here" or "Were I you, I would dismiss such an absurd idea", to be sure, meets the criterion of the linguistically defined subjunctive in the fullest sense. However, the would used in the main clause of the second sentence above as well as could (as in: "I could swim if I had a swimsuit."), should (as in: "Had it not been for that brainiac girl, the class discussion should not have been as animated as it turned out to be."), might (as in: “They might be lost on their way back here."), and the like should altogether be called modal auxiliaries instead of preterit subjunctives as they fail to satisfy the said criterion on two accounts: First, could, would, should, might, etc. are not full verbs but auxiliary verbs; and second, they are used in non-subordinate clauses instead of subordinate clauses. If this is 
the reason why Whitney and Jespersen concur about the historically progressive waning of the subjunctive in English, they are more than justified. Paying obeisance to linguistics and holding school grammar ${ }^{2}$ in abeyance, let us agree to preclude the preterit forms of can, will, shall, may, and other preterit-presents from the range of the subjunctive, because they are not subjunctives in the strictest sense of the term but modals. Then, things will become more transparent.

The difficulty does not end there, however. For both Whitney and Jespersen recognized were alone as a preterit subjunctive still extant in ModE despite the fact that any number of preterit verbs are usable in similar subordinate clauses of contemporary English (e.g., "If I had money enough, I would lend you some."/“If you did it again, I should punish you."). Our puzzlement is why "had", "did", and many another preterit verb used likewise are not taken into account as preterit subjunctives. The explanation of this specific why, though, is not difficult to fathom.

Table 2

Preterit Indicatives and Subjunctives of "be", "have", and "do" (ModE)

\begin{tabular}{|l|l|l|l|l|l|l|}
\hline & Indicative & Subjunctive & Ind. & Sub. & Ind. & Sub. \\
\hline I & was & were & had & had & did & did \\
\hline You & were & were & had & had & did & did \\
\hline He/She & was & were & had & had & did & did \\
\hline We/You/They & were & were & had & had & did & did \\
\hline
\end{tabular}

As exhibited in Table 2, it is only the italicized singular preterit subjunctive were that is recognizably distinct from its indicative counterpart in so far as ModE is concerned. This is what Whitney (1901) meant when he wrote: "No verb except be has a preterit subjunctive that differs from the indicative" (p. 111). All the other preterit subjunctives of ModE belong with the majority have-do camp in that they are identical with their preterit indicative siblings. That is the intent of Jespersen's (1972) statement: "In the preterit only one verb has a subjunctive form that is distinct from the indicative, and that only in the singular: were (indicative was)" (p. 293). Such being the case, had and did in: "If I had money enough, I would lend you some" and "If you did it again, I should punish you" should be judged anything but morphologically distinct preterit subjunctives since they are interpretable as either preterit indicatives or preterit subjunctives, which is why linguists are cautious enough to stay away from identifying them as preterit subjunctives.

Seen also from the recent trend for even were to be increasingly displaced by its indicative sister was (e.g., "as if it were... > as if it was..."), the above-cited observations made by Whitney and Jespersen on the ever-narrowing range of the subjunctive seem quite tenable in a sense more than one. The only outstanding problem that needs to be settled concerns the qualification Whitney (1901) added when he wrote: "The subjunctive has very nearly gone out of use in Modern English" (p. 111). Why did he have to qualify his statement by using such a hedge as "very nearly"? The context makes it palpable that it is not so much because he had in mind the tenacious persistence of were as the last stronghold of the preterit subjunctive of English as doubtless because of the robust survival of the present subjunctive.

Based on Quirk et al. (1972), the two main cases where the present subjunctive (identical to the infinitive

\footnotetext{
${ }^{2}$ In Japanese high schools, for instance, both preterit verbs in subordinate clauses and preterit modal auxiliaries in main clauses are taught as subjunctives indiscriminately.
} 
without $t o$ ) is typically employed in contemporary English are demonstrated below with illustrations borrowed therefrom (see Examples 1-2):

Example (1) In that-clauses dependent upon verbs expressing recommendation, requirement, request, suggestion, etc.

We ask that the individual citizen watch closely any developments in this matter. (Quirk et al., 1972, p. 76)

It is necessary that every member inform himself of these rules. (ibid., p. 76)

There was a suggestion that Brown be dropped from the team. (ibid., p. 76)

Congress has voted/decided/decreed/insisted that the present law be maintained. (ibid., p. 783)

Example (2) In clauses of condition or concession

Though he be the President himself, he shall hear us. (ibid., 1972, p. 783)

Whatever be the reasons for it, we cannot tolerate this disloyalty. (ibid., p. 783)

If any person be found guilty, he shall have the right of appeal. (ibid., p. 748)

Though Quirk et al. (1972) associated the present subjunctive in general with "formal" (pp. 76, 748, 783) style, what is worthy of note in this regard is the repeated mention the members of the Survey of English Usage make of it as "productive" (p. 76) and "occasionally" (p. 783 et passim) used. It is plausibly for this reason that the authors of this monumental grammar of contemporary English dedicate as many as five pages and provide detailed information on the usage of present subjunctive even at the risk of sounding contradictory to their preamble: "The subjunctive is not an important category in contemporary English" (Quirk et al., 1972, p. 76). All this leads us to venture an opinion that it will make better sense not to leave ESL leaners with the impression that the subjunctive is all but eliminated from the synchronic system of English inasmuch as it remains in demonstrably more active use and wider currency than at first sight might appear and commands more serious attention than is now paid it.

The uneven distribution of the indicative and the subjunctive in ModE epitomizes the very contention motivating the present investigation, precisely because close scrutiny discloses a double-decker structure of the mainstreamed indicative and the marginalized subjunctive formed there. As linguists and grammarians say in concert, both the distribution and significance of the indicative are incomparably vast synchronically, to be sure. But that general situation should not obscure the uniquely valuable role fulfilled by the subjunctive, because the present subjunctive in particular is not just productive but also "common in AmE" (Quirk et al., 1972, p. 783). If we admit that the indicative is the order of the day, we should add in the same breath that the persistence of the subjunctive, serving as it does eminently useful purposes albeit within the confines of limited syntactico-semantic environments, is a no less salient feature of ModE. In order to reduce the eliminatory overtones with which the three citations that started this section are invested and pay more amount of heed to the subjunctive for the service it is in within the synchronic system of English, the MH can be a suggestible theoretical option to take. To say the least, teaching the subjunctive, or grammar in general for that matter, as revised through the filter of such a rethinking may be worth experimenting.

\section{Inflection and Periphrasis}

On more grounds than one, inflection and periphrasis can be taken as contrastive linguistic notions. 
Inflection is defined as the morphological change of a lexeme, especially at its ending, realized to mark a different grammatical function, whereas periphrasis by definition is a reliance on a supportive word (e.g., an adverb, an auxiliary, and a preposition) to achieve the same purpose. Physically, as shown below by the graphic image of each, contact (of stem and inflectional ending) characterizes the first, while detachment is a defining feature of the second. Historically speaking, Indo-European languages are prototypically inflectional languages. As it happened, the shapes of a host of Indo-European languages were transformed, as Benveniste (1974) synopsized, by "the replacement of an inflectional category by a periphrastic category within the same functional framework, such as the replacement of the morphological comparison by the syntagma adverb + adjective..." (p. 127) ${ }^{3}$. The history of English is no stranger to that general current of evolution.

\section{Inflection: young-er \\ Periphrasis: more curious}

It hardly needs to be reaffirmed that inflection was a powerful means of marking different grammatical functions of the same lexical unit in OE: The present and past tense forms of verbs were distinguished inflectionally ("binde > band"), the comparison of an adjective was made possible by inflections ("eald > ięldra > ięld(e)st"), a singular noun was pluralized inflectionally ("stān > stānas"), the case distinctions of a pronoun were drawn by inflections ("hwa $>$ hwone $>$ hwæs $>$ hwæm $>$ hwy"), and you go on and on. Being a maximally inflectional and minimally periphrastic language, $\mathrm{OE}$ was incapable of creating such periphrastic tense forms as "will go", "have come", and "be reading", such comparative and superlative forms as "more curious", "most intelligent", or such analytic substitutes for inflectional genitives as "the leg of the table", "the roof of my house". The critical point to note here is that after the erosion of the inflection system that jolted the history of English in late OE and early ME, English could no longer turn to inflections for marking different grammatical categories. Thenceforward, it was inevitably led to take a new course of development as a periphrastic language. Add this nugget of information to your brain's stock. Straight away, you will be able to tell the relative ages of a good many individual expressions.

See Table 3: The secret is inflection or periphrasis, that the inflectional pole of each opposition is historically older as it goes right back to OE, while the periphrastic pole is dated only as far back as ME as a general rule. As was typical of old Germanic languages, OE had only two tense forms, i.e., present (see 3(1) in Table 3) and past tense forms (see 1(1) and 2(1) in Table 3), which were distinguishable inflectionally as already noted above. For the advent of future tense forms per se ("shall/will + infinitive") (see 1(2) in Table 3), the serious development of the perfect ("have + pa. pple.") (see 2(2) in Table 3) and the pluperfect ("had + pa. pple."), we have to wait till the ME stage of the history of English - a fact that underwrites the truth of our information that English began to move away from inflection in the direction of periphrasis with late OE and early ME periods as a turning point. Shall/will [+ infinitive], have [+ pa. pple.], and had [+ pa. pple.] did occur in OE, but they behaved as full verbs meaning "owe", "intend", "possess", and "possessed" respectively. One wonders how OE speakers expressed futurity when they talked about future actions and

\footnotetext{
${ }^{3}$ In the words of Benveniste (1974): "Les transformations... consistent à remplacer une catégorie morphématique par une catégorie périphrastique dans la meme function, par exemple: —remplacement du comparatif morphologique par le syntagme adverbe + adjective; - remplacement de la désinence casuelle par le syntagme préposition + nom" (p. 127). (The replacement of an inflectional category by a periphrastic category within the same functional framework, such as the replacement of the morphological comparison by the syntagma adverb + adjective or the replacement of the case suffix by the syntagma preposition + noun.)
} 
situations. The short answer to that pertinent question is to take it that they used present tense forms of verbs just as ModE speakers do when they say: "The next train leaves at 11 o'clock"; "Fingers crossed that you get well soon"; "If you come with me, I will show you something", and the like. Given that will was a full verb back in OE days, it comes to that $\mathrm{OE}$ speakers used the present tense form of a verb both in the subordinate and main clauses with regard to a hypotactic sentence like "If you come with me, I will show you something".

Table 3

Inflectional and Periphrastic Expressions

\begin{tabular}{lll}
\hline & (1) Inflectional & $(2)$ Periphrastic \\
\hline 1 & drove & will drive \\
2 & rode & have ridden \\
3 & They eat & They are eating \\
4 & commoner & more common \\
5 & I gave her a necklace & I gave a necklace to her \\
6 & He loves her & She is loved by him \\
7 & This knife cuts well & The cake was cut into quarters \\
8 & communications technologies & communication technologies \\
\hline
\end{tabular}

Another approach to the same question is to conceptualize "adverbial tense" as distinct from "verbal tense" and speculate that OE expressed tenses by means of adverbials to cover up for the underdevelopment of verbal tense. Jespersen (1992, p. 254) is among the linguists who issue a challenge to the orthodox identification of tense-indication as the chief duty of verbs that has been prevalent from Aristotle onward and has found its embodiment in such a term for "verb" as verbum temporale (Latin, "time word"), Zeitwort (German, "time word"), or tijd-woord (Dutch, "time word"). He invited our attention to those languages, not excluding English, in which "time is often indicated by means" other than "verbal forms" (Jespersen, 1992, p. 254) and suggested that adverbials are sufficiently effectual to count as such means. This line of speculation obliges us to reconsider, if not disconfirm, the afore-said commonly held belief of centuries' standing in favor of the view that instead of predicate verbs futurity gained expression in such adverbials as "at 11 o'clock", "if you come with me", or "as soon as she arrives" in the infancy of English. The advantage of this rethinking resides in its wider applicability. For another instance, OE speakers said things like: "He repeated what he said before" (in formal ModE: "He repeated what he had said."), thus making up for the lack of the pluperfect by the use of the adverb before. Come to think of it, even ModE speakers say, for instance: "She proceeded to Section 2 after she completed Section 1" more often than "She proceeded to Section 2 after she had completed Section 1" in spoken register in particular. We are reminded of the very tenet of the MH that depicts the synchronic system as an interface where history and now meet. It is a reassuring experience indeed to realize that adverbial tense as history's legacy survives into modern times and is still breathing in full vigor every time ModE speakers say: "The next train leaves at 11 o'clock", "If you come with me, I will show you something", "As soon as she arrives, we will start off", and so on.

Example (3) Ils disent toujours la même chose. (They always say the same thing./They are always saying the same thing.)

Sammelst du Briefmarken? (Do you collect postage stamps?/Are you collecting postage stamps?) 


\section{Hij komt. (He comes./He is coming.) \\ мыл летим в Москву. (I fly to Moscow./I am flying to Moscow.)}

It is a matter of common knowledge that except English ("be -ing") and Spanish ("estar -ando/-iendo") living European languages lack progressive forms. The French, German, Dutch, and Russian sentences shown above (see Example 3) are all in the simple present, yet as contextualized they are interpretable as progressive. The idiomaticization of expressions like "Here comes John", "I kid you not", and "How do you do??" (formerly, "How do you?") in Present-day English solicits our attention and takes us back to the days when English speakers said "per hales in at pe halle dor an aghlich mayster" [There comes in at the hall door a fearsome knight] (Burrow \& Turville-Petre, 1996)", "A Drumme, a Drumme: Macbeth doth come" (Shakespeare, 1605), "What do you read, my Lord?" (Shakespeare, 1600). According to one authority: "The progressive proper develops in Middle English... It can be regarded as a grammaticalised aspectual indicator in the verbal system by 1700" (Rissanen, 1999, p. 216). It can hardly be denied from this that pre-ModE was closer to continental languages of today in that the periphrastic tense form called progressive was not a fully-grown part of its grammatical system. It is comforting to be confirmed here again about the antecedence of inflection (simple tenses) to periphrasis (future, progressive, perfect, and pluperfect tenses).

Together with the triumph of $-s$ plural over mutation plural (e.g., "feet, teeth, geese, geet [later 'goats'], and mice") and -en plural (e.g., "eyen, shoen, kine [later 'cows'], fone [later 'foes'], and oxen") in ME and the introduction of periphrastic of-construction for expressing possessive relationship (e.g., "a leg of the table") to ME, periphrastic comparison should be counted among the major contributions made by Norman French to the shaping of ME grammar. One historical linguist observed "[the periphrastic comparison of adjectives is an example of] the long-term historical trend in English from synthetic to analytic" (Barber, 2000, p. 274) and brought to our notice the recent tendency for the synthetic -er and -est comparison to be replaced by the analytic more and most comparison. "Recently", said Barber (2000): "[M]ore and most have been spreading to adjectives of one syllable" (p. 274), while Crépin (1972, p. 72) broadened the range of "recency" and made a remark to the effect that the periphrastic comparison is favored over the inflectional comparison in $\operatorname{ModE}^{4}$. Likely, Barber and Crépin will be in agreement that such expressions as "one of the most good people that he knew (Iris Murdock, 1958, The Bells, as cited in Crépin, 1972, p. 72) and "A despite don against the most High" (Milton, 1667, Paradise Lost VI, p. 906, as cited in Simpson \& Weiner, 1991) would be more readily acceptable to Present-day English speakers than Alice in Wonderland's "Curiouser and curiouser!" (Carroll, 1865). All these leave us in little doubt that a dual structure of growingly mainstreamed periphrastic comparison and increasingly marginalized inflectional comparison has been forming itself in the collective mind of contemporary English speakers as regards expressions of comparison. Given that, it would not be an altogether misguided teaching strategy to direct ESL learners to make periphrastic errors (e.g., "more short", "most great") rather than inflectional errors (e.g., “* interestinger", "*intelligentest”) if errors are unavoidable at all.

\footnotetext{
${ }^{4}$ In the context where he discussed the comparison of adjectives, Crépin (1972) wrote: "L'anglais moderne préfère la périphrase, forme marquée par rapport à la forme à suffixe. (Modern English prefers the periphrasis, which is markedly distinct from the suffixed comparison)" (p. 72).

${ }_{5}$ The asterisk, prefixed to a linguistic form, denotes "unattested", "non-existent", or "impossible".
} 
Suppose we imposed on two imaginary speakers, one living in OE times and one in ME days, a condition that both the objects ("my friend" and "my son") ought to be pronominalized and told them to construct under that condition a sentence meaning I gave my friend my son. The OE speaker would not mind the order in which dative him ("my friend") and accusative hine ("my son") were arranged. Since the inflections of the two pronominal forms were eminently informative on what his sentence denoted, that is, him was none other than dative and hine accusative wherever they might appear within his sentence, hine $>$ him would not impair communication any more than him > hine. It is the ME speaker who would have to rack her brains how best to facilitate communication, because dative him and accusative hine were syncretized as objective him early in the ME period.

Such was the exact problem ME speakers found themselves face to face with when their language began to attenuate pronominal inflections. One way out of this conundrum was the regulation of the fixed IO (indirect object) > DO (direct object) word order ("I gave him (IO) him (DO).") and the other was the invention of a monotransitive construction with prepositional periphrasis ("I gave him for him"). Crucially for our current purposes, while there was nothing novel syntactically about the ditransitive IO $>$ DO construction, the periphrastic monotransitive construction was a strikingly innovative kind of construction heralding a new era in the history of English. It is not irrelevant to note in this connection that the procreation of prepositional periphrasis is also accountable for the fact that the infinitive, which had gained life as a verbal noun (equivalent to the gerund of ModE) in its plain without-to shape (e.g., I will come [I intend coming], Him were better go [Going would be better for him]), started to be found with preposition $t^{6}$ (e.g., I will go to school to study [ = to studying]) in incrementally abundant tokens in ME. The loss of inflection, coupled with the gain of periphrasis, indeed bears witness to the full extent of the catastrophe that marked off the transition from OE to ME.

What cuts the active voice (see 6(1) in Table 3) apart from the passive voice (see 6(2) in Table 3) in ModE is the difference between inflectional voice and periphrastic voice. From that overt clue, we can justifiably conclude that the active voice precedes the passive historically. This much in itself is nothing to dwell at length upon. What, then, is the difference lying between the middle voice (see 7(1) in Table 3) and the passive voice (see 7(2) in Table 3)? Which is older? The answer is: The first is older than the second for the same reason. Unlike the first opposition (active vs. passive), this second opposition (middle vs. passive) is worth spelling out as it runs into an issue suiting our current discussion.

At the mention of "passive voice", what comes to the mind of whoever knows English as it is spoken today is the periphrastic voice that ModE passive invariably is. Linguistically, though, the passive voice divides up into inflectional type and periphrastic type. In Latin, for example, the inflectional passive was the unmarked mainstreamed passive, whence no radical difference externally between the active voice and the passive voice in Example 4:

Example (4) Active [inflectional]: Parentes liberos amant. (= The parents love the children.)

Passive [inflectional]: Liveri a parentibus amantur. (= The children are loved by the parents.)

\footnotetext{
${ }^{6}$ In ModE, "to school" is a combination of preposition to and noun school, while "to study" is one of infinitive marker to and infinitive study. To OE speakers, however, "to study" was a combination of preposition to and verbal noun study and as such no different semantico-morphologically from "to school".
} 
This is because inflectional passive is the kind prototypical of Indo-European languages and because Latin still remained at a largely inflectional stage in so far as the passive voice was concerned. While the history of English, quite unlike that of Latin, is almost completely destitute of inflectional passive, "one true passive form" (Mitchell \& Robinson, 1982, p. 36) ${ }^{7}$ is found to have survived from pre-English into OE in which hātan (ModE, "be called") was retained as witnessed by "Hu ne hatte hys modor Maria? [Why is his mother not called Mary?] (c 1000 Ags. Gosp. Matt. Xiii. 55, as cited in Simpson \& Weiner, 1991). Although the OE verb hātan and its ME offspring hoten had long since ceased to exist, this "true passive form" left an indelible mark on history by contributing to English the middle voice, which still thrives at this distance of time. Other than 7(1) in Table 3, the following verbs fall into the category called "middle verbs", i.e., verbs which are active in appearance yet passive in meaning:

Example (5) The door won't open.

The new product sells like hot cakes.

The name should read 'Thompson', not 'Thomson'.

This chanson sings well in French.

Call the above-instanced (see Example 5) the first generation of middle voice. The 18th century saw the emergence of the second generation when such a sentence as "The house is building" superseded the ME-based "The house is on building" (i.e., "The house is in the course of building.") and then "The house is a-building". We can entertain the idea of "Uniformitarianism" to which we will come back later (see the last paragraph of this section) and undertake a view that without the foundation laid by the first generation of middle voice, "The house is building", "The potatoes are cooking" (as cited in Summers \& Gadsby, 1995), "The kettle is boiling" (as cited in Hornby, 1989), "Hitchcock's The Birds is now showing", "Flight 1772 for Seoul is now boarding at Gate 18", and suchlike expressions of second-generation middle voice might not have woven into the fabric of ModE. This resuscitation of history strikes us as an example of no slight weight indicative of the long-lived vitality of middle voice as stored in the grammatical repository of English. All things fairly considered, we have reason on our side in redressing the inequities involved in the conventional active-passive binarism that is entrenched in TESL by rehabilitating middle voice as part of the tripartite synchronic voice system of English.

Talking of Latin, its noun phrase consists of an inflectional noun followed by an inflectional adjective. The singularized phrase puer miser (lit., "boy miserable"), for instance, is pluralized as pueri miseri (lit., "boys miserables"), and vir bonus (lit., "man good") as viri boni (lit., "men goods"). The same is the case with French (e.g., une chanson Italienne [lit., "a song Italian"] > des chansons Italiennes [lit., "songs Italians"]), Spanish (e.g., una mano caliente [lit., "a hand warm"] > unas manos calientes [lit., "hands warms"]), and their relatives. This is because in Romance languages, the adjectival component of the noun phrase is bound to inflect in sync with its nominal counterpart in such a way that a singular noun should be neatly aligned with a singular adjective and a plural noun with a plural adjective.

To see that English noun phrases used to be composed of similarly inflected adjectives and nouns that agreed with each other in case, gender, and number, we need only pause to consider, for instance, why the

${ }^{7}$ By "true passive", Mitchell and Robinson mean the prototypical, inflectional type of passive. 
ModE adjectival phrase the good means "good people" in principle. Table 4 is meant to provide a quick view of the way the adjectival parts of OE noun phrases meaning "the good man" and "the good men" inflected. It is shown that the weak inflection of the adjective gōd as followed by a masculine singular noun ("mann") was turned into gōda and that as followed by a plural noun ("menn") it was rendered into gōdan. As it happened, the singular $g \bar{o} d a$ and the plural gōdan fell together during the course of the ME period as gōde, whose syllabic second vowel /a/ in turn was deleted in the fifteenth century with a final consequence that gōde was reshaped as good, thus completing the process of demorphologization.

One side effect of that process of demorphologization lies in the progressive semantic indeterminacy of the adjectival phrase "the + adjective". Since the nouns ("mann" and "menn") within "se gōda mann" and "pā gōdan menn" could be omitted in OE without detriment to communication, OE speakers just said "se gōda" and "pā gōdan" not infrequently - a performance expediency that got idiomaticized and survived into ME. Due to the combination of the fifteenth-century leveling of adjectival inflections and the much earlier decay of the declension of the definite article, however, the "the + adjective" phrase started to lead listeners astray, for the morphological distinction formerly drawn between "se gōda" and "pā gōdan" was now completely obliterated. In avoidance of communicational embarrassment, ModE speakers have relegated "the + adjective" ("the good") to a case where it means "adjective + plural noun" ("good people") in principle.

Table 4

Weak Inflection of Adjective gōd ("good")

\begin{tabular}{|l|l|l|l|}
\hline NOMINATIVE case & OE & ME & ModE \\
\hline singular/masculine & se gōda mann & pe gōde man & the good man \\
\hline plural & pā gōdan menn & pe gōde men & the good men \\
\hline
\end{tabular}

To return to the main current of discussion, an English adjective no longer inflects in accord with its noun accompaniment in principle. The singularized phrase "a dark room", therefore, should be pluralized as "dark rooms" and not "*darks rooms". That is the mainstreamed part of ModE grammar that should take priority in teaching and learning. However, this mainstreamed grammar is not without its marginalized companion, which is of such importance that in effect ModE could not do without it. The marginal in question is the pair of inflectional adjectives called demonstratives (i.e., "this/these, that/those") which outlived the dismantling of the system of adjectival inflection. The inventory of demonstratives (see Table 5), though made up of only four forms, is a remarkable example of the full force of history in place within the synchronic system and is only too valuable to be brushed aside as a heterogeneous part out of tune with the synchronic grammar. This can certainly be one paradigm case of the meeting of history and now within a synchronic system ("synchro-diachronic concomitance") that is powerful enough to awaken TESL professionals to the pressing need to let the marginal glow and come into its own as history's legacy in situ.

Table 5

Inflections of Demonstrative Adjectives (ModE)

\begin{tabular}{|l|l|}
\hline sg. adjective + sg. noun & pl. adjective + pl. noun \\
\hline This book & These books \\
\hline That tree & Those trees \\
\hline
\end{tabular}


Having said that and observed that ModE still feeds off the OE adjectival inflection, it must be borne in mind that the mainstreamed grammar now stipulates that a noun phrase be composed of a singular adjective followed by either a singular noun or a plural noun ("adjective (sg.) + noun (sg./pl.)"). It is due to this grammatical straitjacket that ModE speakers are required to say "two dark rooms" (not "*two darks rooms"), “a three-volume novel” (not “*a three-volumes novel”), "a five-year-old boy” (not "**a five-years-old boy"), and so forth. While this rule still remains in force, a keen observer of Present-day English cannot fail to notice that there has been a notable recent trend toward "adjective (pl.) + noun (sg./pl.)". Examples are furnished by "a goods train" (1850, as cited in Simpson \& Weiner, 1991), "the Contagious Diseases Act" (as cited in Jespersen, 1992, p. 208), "a Humanities subject" (as cited in Sinclair, Hanks, Fox, Moon, \& Stock, 1988), “a savings account”, “communications technologies" (see 8(1) in Table 3), "materials development", and suchlike phrases where a pluralized adjectival noun is grafted on to a noun. These syntagmas may well be described as noteworthy deviations cropping up to breach the mainstreamed grammatical rule of ModE. But why does this occur at all? One solution will be to see it in the light of a claim called Uniformitarianism ${ }^{8}$ and accept that this particular locality of ModE grammar is reverting, in a way, to the bygone age when the occurrence of a plural adjective wherever the call for it was felt was a full part of the grammatical system (e.g., "pā gōdan menn").

\section{Conclusions}

"Regular" and "irregular" are a pair of terms busily employed in school grammar and school TESL. Ride-rode-ridden, it is said, is an irregular conjugation as opposed to the regular talk-talked-talked. Tree (sg.)-trees (pl.) is a regular declension, whereas woman (sg.)-women (pl.) is an irregular one, they say. "Exception" and its derivative "exceptional" are another flourishing pair of terms much favored by English teachers. Thebes (pl.) and the Ginza ("the + place-name"), for example, are explained away as exceptional toponymic formations. Such proverbs as Manners makes man and Money makes the mare to go are often cited as typifying an exceptional concord. Given that it is humanly impossible to present a fully lucid grammatical exposition of the whole universe of a natural language, the use of the terms "irregular", "exception", and "exceptional" in itself is nothing to be castigated. Remaining within bounds, it could be a reasonable teaching strategy. What is pernicious from a terminological point of view is the bias such terms connote against the marginalized part of a synchronic grammar. The fact that no scientifically neutral pedagogical terms are in existence for referring to the marginalized grammar as no less vital part of a synchronic grammar bespeaks a serious lacuna in traditional thinking about language teaching, and it is this lacuna which has been doing a great disservice to any true cause of TESL worthy of the name.

Amongst the harvests brought in by Ohashi (2013, forthcoming) are the findings that a language consists of change-proof part and change-prone part and that quite often change-proof conservatisms are informed by such key conceptual denominators as simplicity, iteration, privacy, and involvement. What this means is that the simplest and commonest kind of forms appertaining to personal commitment tend to be resistive to innovations and stay in their old guises at the risk of being left behind the general development of

\footnotetext{
${ }^{8}$ William Labov (1978) described "Uniformitarianism" as "the claim that the same mechanisms which operated to produce the large-scale changes of the past may be observed operating in the current changes taking place around us" (p. 161).
} 
the language. Consequent on this, it often happens that such forms are degrammaticalized in various ways. Suppletivism as illustrated by good-better-best, bad-worse-worst, much-more-most, etc., where simplicity, iteration, and subjective judgment are involved, is a prime example of this, but the same holds true of the lexicalization of the $\mathrm{OE}$ plural formation by vowel mutation such as feet, men, and lice, the deparadigmatization of ME comparisons like out-utter-utmost, old-elder-eldest, late-latter-last, etc., in ModE, and the petrification of the ME (Northern) agreement between plural subject and $s$-final present finite as entrenched in the proverb Manners makes man.

The point being reiterated here is that marginalization, including no small numbers of instances of degrammaticalization, lexicalization, or idiomaticization, is the very means by which history's legacy can resist innovations and weather the vicissitudes of language. From the viewpoint of the MH, which conceptualizes a language-internal dual structure of change-prone floats superposed to change-proof sediments and depicts a synchronic system as a work carved out collaboratively by history and now, heritages of history are nothing to be left out of account as exceptions or anomalies but something to be resuscitated and made to see the light of day not just in linguistic studies but also in activities of teaching any natural language. Such has been the major argument advanced and developed in this paper.

Whitney (1901) wrote: “The history of language has a great deal to tell us about the history of man, and of what he has done in the world" (p. 7). Which is true enough. But it is also true to say that language has a great deal to tell us about its own past (equivalent to "marginalized part"), as well as its present (equivalent to "mainstreamed part"). Given the theoretical inevitability that obliges historical heritages to fall foul of the mainstreamed synchronic system, it will follow that a thesis of language as a bipartite entity formed by the structural opposition of mainstream and marginal as allies in the molding of language should be called into being. It is in recognition of the need to cogently deal with this blind spot that the idea of "synchro-diachronic concomitance" as part of the MH has been brought into discussion. For now, suffice it to confirm that MH-based language teaching proposes to broaden the range of a target grammar beyond a narrowly defined synchronic grammar in which current TESL is clothed, in order thereby to widen the horizons of learners of English as a second language.

\section{References}

Barber, C. (2000). The English language: A historical introduction. Cambridge: Cambridge University Press.

Benveniste, E. (1974). Problems of general linguistics II (Problèmes de Linguistique Générale II). Paris: Gallimard.

Burrow, J. A., \& Turville-Petre, T. (2005). A book of middle English (3rd ed.). Oxford: Blackwell.

Burrow, J. A., \& Turville-Petre, T. (Eds.). (1996). Sir Gawain and the green knight. A book of Middle English (3rd ed.). Oxford: Blackwell.

Carroll, L. (1865). Alice's adventures in wonderland. New York: Dover Publications.

Chaucer, G. (1382-1385). Troilus and Criseyde (Book II). In J. A. Burrow \& T. Turville-Petre (Eds.), A book of Middle English (3rd ed.). Oxford: Blackwell.

Crépin, A. (1972). The history of the English language (Histoire de la langue Anglaise). Paris: Presses Universitaires de France. de Saussure, F. (1916). Course in general linguistics (Cours de linguistique générale). Paris: Payot.

Hornby, A. S. (Ed.). (1989). Oxford advanced learner's dictionary of current English (4th ed.). Oxford: Oxford University Press. Jespersen, O. (1972). Essentials of English grammar. London: George Allen \& Unwin.

Jespersen, O. (1992). The philosophy of grammar. Chicago: The University of Chicago Press.

Labov, W. (1978). Sociolinguistic patterns. Philadelphia: University of Pennsylvania Press. 
Mitchell, B., \& Robinson, F. C. (1982). A guide to old English (6th ed.). Oxford: Blackwell.

Ohashi, K. (2011). Prolegomena to marginalization hypothesis. Us-China Foreign Language, 12.

Ohashi, K. (2013, forthcoming). Revisiting uniformitarianism (Seiitsusei-genri saihō). Polyglossia, 25.

Quirk, R., Greenbaum, S., Leech, G., \& Svartvik, J. (1972). A grammar of contemporary English. London: Longman.

Rissanen, M. (1999). Syntax. In R. Lass (Ed.), The Cambridge history of the English language (Vol. III). Cambridge: Cambridge University Press.

Shakespeare, W. (1600). Hamlet. In W. J. Craig (Ed.), The complete works of Shakeapeare. London: Oxford University Press. Shakespeare, W. (1605). Macbeth. In W. J. Craig (Ed.), The complete works of Shakeapeare. London: Oxford University Press. Simpson, J. A., \& Weiner, E. S. C. (Eds.). (1991). Oxford English dictionary (2nd ed.). Oxford: Oxford University Press.

Sinclair, J., Hanks, P., Fox, G., Moon, R., \& Stock, P. (Eds.). (1988). Collins COBUILD English language dictionary. London: Collins.

Summers, D., \& Gadsby, A. (Eds.). (1995). Longman dictionary of contemporary English (3rd ed.). Essex: Longman.

Whitney, W. D. (1896). The life and growth of language: An outline of linguistic science. New York: D. Appleton and Company.

Whitney, W. D. (1901). An English grammar of the higher grades in grammar schools. Boston: Ginn \& Company. 